\title{
Effects of Salinity and Mycorrhizal Inoculation (Glomus fasciculatum) on Growth Responses of Grape Rootstocks (Vitis spp.)
}

\author{
D. Belew ${ }^{1}$, T. Astatkie ${ }^{2 *}$, M.N. Mokashi ${ }^{3}$, Y. Getachew ${ }^{1}$, C.P. Patil ${ }^{3}$ \\ (1) Jimma University College of Agriculture and Veterinary Medicine, P.O. Box 307, Jimma, Ethiopia \\ (2) Nova Scotia Agricultural College, P.O. Box 550, Truro, Nova Scotia, B2N 5E3, Canada \\ (3) University of Agricultural Sciences, Dharwad 580005, Dharwad, India
}

Submitted for publication: December 2009

Accepted for publication: January 2010

Key words: Fungus, spore count, root colonisation, internode length

\begin{abstract}
A pilot experiment was conducted to determine the effects of soil salinity and inoculation with arbuscular mycorrhizal fungus (Glomus fasciculatum) on growth (shoot length, leaf number, internode length, and total dry weight), spore count and root colonisation of grape rootstocks (Salt Creek, St. George, Dogridge and 1613). Analysis of variance results revealed that increasing salinity reduces growth, spore count and root colonisation, with St. George rootstock showing the highest reduction. Although all rootstocks responded positively to mycorrhizal inoculation, the extent of host preference varied significantly. Dogridge was the least preferred, while the 1613 rootstock was the most preferred. The arbuscular fungal symbiosis increased vegetative growth, with 1613 attaining the highest growth under saline conditions. All the inoculated rootstocks exhibited longer internodes, indicating the beneficial role of mycorrhizal inoculation for improving plant growth and salt tolerance. Based on overall growth and total dry matter accumulation, the salt tolerance ranking of the four rootstocks, in decreasing order, was Dogridge, Salt Creek, 1613 and St. George.
\end{abstract}

\section{INTRODUCTION}

Grapes are important fruit crops in India, with over 40000 hectares grown across the country. Major grape-growing states include Maharashtra, Andhra Pradesh, Karnataka and Tamil Nadu in central and southern India; and Punjab, Haryana and Uttar Pradesh in northern India. Since more than $90 \%$ of the grapegrowing area is in the semi-arid regions of Maharashtra, northern Karnataka and Andhra Pradesh, productivity in these states is becoming constrained by water scarcity and soil salinity (Satisha \& Prakash, 2006).

Soil salinity is a widespread problem that restricts plant growth and biomass production, especially in arid, semi-arid and tropical areas (Apse et al., 1999). Salinity affects plants through nonspecific and specific mechanisms. The nonspecific mechanism is related to the decreasing osmotic potential of the soil solution that impedes transpiration and photosynthesis (Shannon \& Grieve, 1999). Specific mechanisms relate to ion uptake and altered physiological processes resulting from toxicity, deficiency, or changes in mineral balance (Shannon \& Grieve, 1999; Hasegawa et al., 2000). Salt tolerance is the ability of plants to survive and grow under saline conditions and is a variable trait that depends on many factors, including species (Volkmar et al., 1998). Plants generally vary in response to soil salinity and grapes (vines) in particular have been defined as moderately sensitive to salinity (Downton, 1977). However, different rootstocks show different levels of osmotin gene expression in reaction to salt stress (Agaoglu et al., 2004). Osmotin is a stress responsive, multifunctional $24 \mathrm{kDa}$ basic protein (Payne et al., 1988) belonging to the PR-5 protein family providing osmo-tolerance (Pierpoint et al., 1990) to plants.
Arbuscular mycorrhizal (AM; Glomus fasciculatum) fungi are ubiquitous among a wide array of soil microorganisms inhabiting the rhizosphere (Giri et al., 2003). The symbiotic association of a plant with AM fungi allows access to mobile nutrients in nutrientpoor soils (Marschner \& Dell, 1994). AM fungi constitute an integral component of the natural ecosystem, and are known to exist in saline environments where they improve early plant growth and tolerance to salinity (Aliasgharzadeh et al., 2001). Many researchers have reported that AM fungi could enhance the ability of plants to cope with salt stress (Yano-Melo et al., 2003; Rabie, 2005) by improving plant nutrient uptake (Asghari et al., 2005) and ion balance (Giri et al., 2007), protecting enzyme activity (Giri \& Mukerji, 2004), and facilitating water uptake (Ruiz-Lozano \& Azcon, 1995).

In salt-stressed soil, AM fungi are thought to improve the supply of mineral nutrients to the plants, especially the supply of $\mathrm{P}$, as it tends to be precipitated by ions like $\mathrm{Ca}^{2+}, \mathrm{Mg}^{2+}$ and $\mathrm{Zn}^{2+}$ (Al-Karaki et al., 2001). Giri et al. (2003) reported that AM fungi counter-balanced the adverse effects of salinity stress and thereby increased plant growth. Rabie (2005) suggested that AM fungi protected the host plants against the detrimental effects of salt.

An increasing occurrence of soil salinity, drought and declining productivity of grape varieties in India has made use of a suitable rootstocks imperative (Singh \& Sharma, 2005). In recent years, the majority of new vineyards have been planted using grafted plants, and this trend is expected to increase in years to come. However, the response of rootstocks inoculated with the AM fungus to varying levels of salinity has not been studied. Therefore, an experiment was conducted to determine the effects of salinity and 
mycorrhizal (Glomus fasciculatum) inoculation on plant growth (shoot length, number of leaves, internode length, and total dry weight), spore count, and root colonisation in four different grape rootstocks (Vitis spp.).

\section{MATERIALS AND METHODS}

\section{Experimental site}

The experimental site, Dharwad, is situated in the northern transitional tract of Karnataka, India, $15^{\circ} 26 \mathrm{~N}$ and $70^{\circ} 07 \mathrm{E}$, at an altitude of $678 \mathrm{~m}$ above sea level (a.s.1.). The average annual rainfall of this area is $807 \mathrm{~mm}$, which is evenly distributed from May to November. The mean maximum temperature ranges from $27.1^{\circ} \mathrm{C}$ to $36.6^{\circ} \mathrm{C}$, and the mean minimum between $12.4^{\circ} \mathrm{C}$ and $21.3^{\circ} \mathrm{C}$. The relative humidity fluctuates between 34 and $84 \%$.

\section{Propagation}

Planting material of the four grape rootstocks, namely Dogridge (V. champini), Salt Creek (V. champini), St. George (V. rupestris) and 1613 ( $V$. riparia $\times$ V rupestris $\times$ V vinifera $\times$. candicans $\times$. labruska), was obtained from the Indian Institute of Horticultural Research (IIHR) in Bangalore, India. Hardwood cuttings were selected from eight-year-old mother vines and cut into sections with three to four nodes each. The cuttings were dipped in running cold water for $24 \mathrm{~h}$ to leach out growth inhibitors and to facilitate rooting. They were planted in raised nursery beds (soil medium), allowed to root and grow for two months, and then transferred to polyethylene bags of $15 \times 22.5 \mathrm{~cm}$. All the necessary cultural operations, including irrigation, weeding, and fertilisation (vermicompost), were done as required.

\section{Arbuscular mycorrhizal (AM) inoculation}

The cuttings were inoculated with $G$. fasciculatum in the nursery using $5 \mathrm{~g}$ of inoculum per cutting placed at $5 \mathrm{~cm}$ depth. The inoculum potential was determined using the most probable number method (Alexander, 1982). After inoculation, a thin layer of soil was added, and the cuttings were planted and covered with soil. Two-month-old mycorrhiza-inoculated rooted cuttings were transferred to polyethylene bags and grown for four months (until they attained pencil-size shoot girth), after which they were subjected to salinity stress.

\section{Application of salinity treatments}

Salinity treatments commenced six months after inoculation with G. fasciculatum. The rooted cuttings were removed carefully from the polyethylene bags and the soil adhering to the roots was gently removed, leaving approximately $20 \%$ of its initial volume (to minimise transplanting shock), and transferred to $30 \times 30 \mathrm{~cm}$ earthen pots. The pots were filled with naturally salt-affected soil with an electrical conductivity of $0.5,2,4,6$ and $8 \mathrm{dS} / \mathrm{m}$ at $25^{\circ} \mathrm{C}$ that was obtained from soils found in the Gangawati Agricultural Research Station of the University of Agricultural Sciences, Dharwad (Raichur district, Northern Karnataka, India). After the salt treatment, the potted plants were allowed to grow for 120 days (January 25 to May 25).

\section{Irrigation and maintenance of salinity levels}

To maintain the set level of salinity, the plants were given a measured volume of irrigation water (EC of $0.25 \mathrm{dS} / \mathrm{m}$ ). To determine the required volume of irrigation water, similar pots filled with soil of different electrical conductivity were placed in large plastic buckets and irrigated with a known volume of water, and then kept for seven hours to attain field capacity. Afterwards, the drained water was measured and subtracted from the total volume of water applied. The value obtained (mean of four pots) was considered as optimum to keep the soil moisture at field capacity. Each pot-grown plant was given $1.3 \mathrm{~L}$ during the first two months, and $1.5 \mathrm{~L}$ during the next two months, every other day at the same time of the day.

\section{Response measurements}

At the end of the four-month experimental period, the shoot length of each plant was measured $(\mathrm{cm})$ from root-shoot juncture to tip of the vine. The internode length $(\mathrm{cm})$ was measured between the $3^{\text {rd }}$ and the $4^{\text {th }}$ node from the tip of the shoot, where the leaves were fully opened and the internodes well developed. Shoot length, internode length and number of leaves per vine were measured on the same three randomly selected plants per treatment. After separating the shoots and the roots of the plants, the roots were washed to remove the soil adhering to them. The shoots and roots were oven dried at $70^{\circ} \mathrm{C}$ until a constant dry weight was obtained. The shoot and root dry matter were added to get the total dry weight.

\section{Spore count and root colonisation}

Extra-matrical chlamydospores produced by G. fasciculatum were counted following the wet sieving and decanting method (Gerdemann \& Nicolson, 1963). Fifty grams of a representative soil sample was drawn from each pot, suspended in a sufficient quantity of water and stirred thoroughly. After the soil was allowed to settle for one minute, each sample was decanted onto the sieves. The suspension was passed through a set of sieves with mesh size of $850,300,250,150$ and $37 \mu \mathrm{m}$ respectively. The spores collected on the sieves of 250 and $37 \mu \mathrm{m}$ were transferred to watch glasses. A spore count was carried out using a stereomicroscope (100x) and expressed as number of chlamydospores per $50 \mathrm{~g}$ of soil. Arbuscular mycorrhizal fungus infection was assessed from randomly selected root material after cutting secondary and tertiary root samples into $1-2 \mathrm{~cm}$ pieces. Roots were cleaned in $\mathrm{KOH}$ and stained in $0.05 \%$ trypan blue (Phillips \& Hayman, 1970). The percentage of root colonisation was estimated by adopting the gridline intersect method (Giovanetti \& Mosse, 1980). Fine individual root segments were mounted on slides and observed under a light microscope. The frequency of AM fungus colonisation was calculated as the percentage of root segments containing hyphae, arbuscules or vesicles.

\section{Statistical analysis}

Data for the above response variables were analysed as a $2 \mathrm{x}$ $4 \times 5$ factorial design with three replications. The factors were AM fungus (AM: with and without), grape rootstock (RS: 1613, Dogridge [D], Salt Creek [SC] and St. George [SG]), and salinity (Sal: $0.5,2,4,6$ and $8 \mathrm{dS} / \mathrm{m}$ ). The analysis of variance (ANOVA) was completed using the mixed procedure of SAS (SAS, 2003). Model assumptions, namely constant variance and normal distribution assumptions on the error terms, were verified using the methods described in Montgomery (2009). When violated, appropriate transformation was applied to the response measurements, but the means reported in the tables and in Fig. 2 were back-transformed to the original scale to facilitate easier interpretation. For significant effects, starting from the highest- 
order interaction, the least squares means were compared and letter groupings were generated. A $1 \%$ level of significance was used for generating letter groupings for the means of treatment combinations from two- and three-factor interaction effects to protect the Type I error rate from over-inflation. Letter groupings were done using a 5\% level of significance when only a main effect, but not an interaction effect, was significant. The correlation coefficients among the growth response variables and nitrogen, phosphorus, sodium and chloride in the plant were also calculated to determine the type and strength of relationships.

\section{RESULTS}

\section{Shoot length $(\mathrm{cm})$ and internode length $(\mathrm{cm})$}

The ANOVA results show that the interaction effect of rootstocks and salinity on shoot length was significant (Table 1). A comparison of the means of the 20 rootstocks by salinity treatment combinations (Table 2) revealed that rootstock 1613 had the longest mean shoot length $(61.5 \mathrm{~cm})$ in the soil with the lowest salinity level (EC of $0.5 \mathrm{dS} / \mathrm{m}$ ). This was followed by Dogridge and Salt Creek at the lowest salinity level, with a mean shoot length of $50.1 \mathrm{~cm}$ and $46.7 \mathrm{~cm}$ respectively. At the lowest salinity level, St. George had the shortest shoots $(22.4 \mathrm{~cm})$. The longest internode mean $(7.08 \mathrm{~cm})$ was obtained in Dogridge grown at the lowest salinity level $(0.5 \mathrm{dS} / \mathrm{m})$, while the shortest internode mean $(1.67 \mathrm{~cm})$ was obtained in St. George at the salinity level of $8 \mathrm{dS} / \mathrm{m}$ (Table 2). The main effect of the AM fungus, but not its interaction with either of the other two factors, was significant (Table 1), suggesting that inoculation with $G$. fasciculatum increased the internode length of all rootstocks, regardless of salinity stress (the length averaged across rootstocks and salinity was $3.58 \mathrm{~cm}$ compared to $3.34 \mathrm{~cm}$ without inoculation). In general, as the salinity level increased, both shoot length and internode length decreased. These different effects of salinity on the four rootstocks when they were not inoculated with $G$. fasciculatum are illustrated in Fig. 1.

\section{Number of leaves per vine}

The interaction effect of AM fungus and rootstock, and the main effect of salinity on leaf number were significant (Table 1). Inoculation with $G$. fasciculatum increased the mean number of leaves of 1613 and Dogridge from 13.5 to 17.1 and from 10.8 to 16.7 respectively. However, it had no effect on Salt Creek and
St. George (Table 3). Increasing salinity generally resulted in a decreased leaf number (from a mean of 17.6 in $0.5 \mathrm{dS} / \mathrm{m}$ to 7.42 in $8 \mathrm{dS} / \mathrm{m}$ ), regardless of rootstock and inoculation (Table 4).

\section{Total dry weight (g)}

None of the interaction effects on total dry weight was significant (Table 1). However, all three main effects were significant. Inoculation with $G$. fasciculatum increased the total dry weight from $7.2 \mathrm{~g}$ to $8.8 \mathrm{~g}$ (data not shown). As salinity increased, total dry weight decreased from $13.4 \mathrm{~g}$ (at $0.5 \mathrm{dS} / \mathrm{m}$ ) to $5.8 \mathrm{~g}$ (at 6 $\mathrm{dS} / \mathrm{m}$ ), and then remained constant (Table 4). The total dry weight of the rootstocks varied, with the highest mean $(13.0 \mathrm{~g})$ for the Salt Creek rootstock, followed by $8.8 \mathrm{~g}$ for Dogridge, $7.7 \mathrm{~g}$ for 1613, and $4.5 \mathrm{~g}$ for St. George.

\section{Correlations}

Plant growth responses (shoot length, internode length, leaf number, total dry matter content) were positively correlated with plant $\mathrm{N}$ and $\mathrm{P}$ content. In contrast, these growth responses and plant $\mathrm{N}$ and $\mathrm{P}$ content were highly negatively correlated with plant $\mathrm{Na}$ and $\mathrm{Cl}$ content (Table 5).

\section{Spore count}

The three-way interaction effect on spore count was significant (Table 1). As shown in Figure 2, the highest spore counts (mean of 395 to 420 per $50 \mathrm{~g}$ dry soil) in the rhizosphere soil were obtained from inoculated 1613 at the lower salinity levels $(0.5$ to $4 \mathrm{dS} / \mathrm{m})$. However, a salinity of $6 \mathrm{dS} / \mathrm{m}$ gave a similarly high number of spores as salinities of 2 and $4 \mathrm{dS} / \mathrm{m}$. Increasing the salinity level resulted in a decreased spore count in the other rootstocks. Figure 2 also depicts the increase in spore count when inoculated with AM fungus.

\section{Root colonisation}

The interaction effect of AM fungus and rootstock, and the main effect of salinity on root colonisation were significant (Table 1). All four rootstocks responded positively to the mycorrhizal symbiosis. The highest root colonisation (74\%) was obtained from mycorrhiza-inoculated 1613, followed by Salt Creek and St. George (61 and 60\% respectively) (Table 3). The mean root colonisation of all four rootstocks when not inoculated was similar (Table 3). Root colonisation generally decreased with increasing salinity (Table 4).

\section{TABLE 1}

P-values for testing the main and interaction effects of inoculation with arbuscular mycorrhizal fungus (AM) and salinity (Sal) on shoot length, internode length, leaf number, total dry weight, spore count and root colonisation of grape rootstocks (RS). Significant effects that need further multiple means comparison are shown in bold face.

\begin{tabular}{|c|c|c|c|c|c|c|}
\hline $\begin{array}{l}\text { Source of } \\
\text { variation }\end{array}$ & $\begin{array}{l}\text { Shoot } \\
\text { length }\end{array}$ & $\begin{array}{l}\text { Internode } \\
\text { length }\end{array}$ & $\begin{array}{c}\text { Leaf } \\
\text { number }\end{array}$ & $\begin{array}{c}\text { Total dry } \\
\text { weight }\end{array}$ & $\begin{array}{l}\text { Spore } \\
\text { count }\end{array}$ & $\begin{array}{c}\text { Root } \\
\text { colonisation }\end{array}$ \\
\hline $\mathrm{AM}$ & 0.067 & 0.001 & 0.001 & 0.001 & 0.001 & 0.001 \\
\hline RS & 0.001 & 0.001 & 0.001 & 0.001 & 0.001 & 0.001 \\
\hline $\mathrm{AM} * \mathrm{RS}$ & 0.340 & 0.892 & 0.005 & 0.165 & 0.001 & 0.001 \\
\hline Sal & 0.001 & 0.001 & 0.001 & 0.001 & 0.001 & 0.001 \\
\hline $\mathrm{AM}^{*} \mathrm{Sal}$ & 0.166 & 0.842 & 0.965 & 0.516 & 0.022 & 0.164 \\
\hline RS*Sal & 0.016 & 0.001 & 0.933 & 0.243 & 0.001 & 0.999 \\
\hline $\mathrm{AM}^{*} \mathrm{RS}^{*} \mathrm{Sal}$ & 0.355 & 0.955 & 0.814 & 0.977 & 0.001 & 0.997 \\
\hline
\end{tabular}


TABLE 2

Mean shoot length $(\mathrm{cm})$ and internode length $(\mathrm{cm})$ for the treatment combinations of grape rootstocks (RS: 1613, Dogridge [D], Salt Creek [SC] and St. George [SG]) and salinity (Sal) levels.

\begin{tabular}{|c|c|c|c|}
\hline RS & Sal & Shoot length (cm) & Internode length $(\mathrm{cm})$ \\
\hline 1613 & 0.5 & $61.5 \mathrm{a}^{*}$ & $4.52 \mathrm{~cd}$ \\
\hline 1613 & 2 & $41.1 \mathrm{bcd}$ & 4.20 def \\
\hline 1613 & 4 & $34.7 \mathrm{def}$ & $3.71 \mathrm{fgh}$ \\
\hline 1613 & 6 & $32.7 \mathrm{defg}$ & $2.91 \mathrm{ij}$ \\
\hline 1613 & 8 & 25.5 fghi & $2.41 \mathrm{jk}$ \\
\hline $\mathrm{D}$ & 0.5 & $50.1 \mathrm{~b}$ & $7.08 \mathrm{a}$ \\
\hline $\mathrm{D}$ & 2 & $36.0 \mathrm{def}$ & $5.65 \mathrm{~b}$ \\
\hline $\mathrm{D}$ & 4 & $32.9 \mathrm{defg}$ & $5.08 \mathrm{bc}$ \\
\hline $\mathrm{D}$ & 6 & $29.9 \mathrm{efgh}$ & $3.34 \mathrm{hi}$ \\
\hline $\mathrm{D}$ & 8 & 23.3 ghij & $2.74 \mathrm{j}$ \\
\hline $\mathrm{SC}$ & 0.5 & $46.7 \mathrm{bc}$ & $4.41 \mathrm{cde}$ \\
\hline $\mathrm{SC}$ & 2 & 39.5 cde & 3.99 defg \\
\hline $\mathrm{SC}$ & 4 & 34.4 def & $3.86 \mathrm{efgh}$ \\
\hline $\mathrm{SC}$ & 6 & $29.8 \mathrm{efgh}$ & $3.49 \mathrm{gh}$ \\
\hline $\mathrm{SC}$ & 8 & 23.3 ghij & $2.88 \mathrm{ij}$ \\
\hline SG & 0.5 & 22.4 ghij & $2.74 \mathrm{j}$ \\
\hline SG & 2 & $19.3 \mathrm{hijk}$ & $2.59 \mathrm{j}$ \\
\hline SG & 4 & $16.5 \mathrm{ijk}$ & $2.08 \mathrm{kl}$ \\
\hline SG & 6 & $13.5 \mathrm{jk}$ & $2.03 \mathrm{kl}$ \\
\hline SG & 8 & $10.6 \mathrm{k}$ & 1.671 \\
\hline
\end{tabular}

"For each response, means followed by the same letter are not significantly different.

\section{TABLE 3}

Means of leaf number and root colonisation (\%) for the treatment combinations of arbuscular mycorrhizal (AM) fungus and grape rootstock (RS: 1613, Dogridge [D], Salt Creek [SC] and St. George [SG]).

\begin{tabular}{lccc}
\hline AM & RS & $\begin{array}{c}\text { Leaf } \\
\text { number }\end{array}$ & $\begin{array}{c}\text { Root } \\
\text { colonisation (\%) }\end{array}$ \\
\hline With & 1613 & $17.1 \mathrm{a}^{*}$ & $74 \mathrm{a}$ \\
With & $\mathrm{D}$ & $16.7 \mathrm{a}$ & $48 \mathrm{c}$ \\
With & $\mathrm{SC}$ & $12.7 \mathrm{~b}$ & $61 \mathrm{~b}$ \\
With & SG & $11.9 \mathrm{~b}$ & $60 \mathrm{~b}$ \\
Without & 1613 & $13.5 \mathrm{~b}$ & $41 \mathrm{~d}$ \\
Without & $\mathrm{D}$ & $10.8 \mathrm{~b}$ & $39 \mathrm{~d}$ \\
Without & $\mathrm{SC}$ & $12.3 \mathrm{~b}$ & $42 \mathrm{~d}$ \\
Without & $\mathrm{SG}$ & $11.3 \mathrm{~b}$ & $42 \mathrm{~d}$ \\
\hline
\end{tabular}

"For each response, means followed by the same letter are not significantly different.

\section{TABLE 4}

Mean leaf number, total dry weight ( $\mathrm{g}$ ) and root colonisation (\%) for the five salinity (Sal) levels.

\begin{tabular}{cccc}
\hline Sal & $\begin{array}{c}\text { Leaf } \\
\text { number }\end{array}$ & $\begin{array}{c}\text { Total dry } \\
\text { weight (g) }\end{array}$ & $\begin{array}{c}\text { Root } \\
\text { colonisation (\%) }\end{array}$ \\
\hline 0.5 & $17.6 \mathrm{a}$ & $13.4 \mathrm{a}^{*}$ & $57 \mathrm{a}$ \\
2 & $15.6 \mathrm{~b}$ & $9.6 \mathrm{~b}$ & $54 \mathrm{ab}$ \\
4 & $14.6 \mathrm{~b}$ & $7.5 \mathrm{c}$ & $53 \mathrm{~b}$ \\
6 & $11.3 \mathrm{c}$ & $5.8 \mathrm{~d}$ & $50 \mathrm{c}$ \\
8 & $7.4 \mathrm{~d}$ & $5.6 \mathrm{~d}$ & $46 \mathrm{~d}$ \\
\hline
\end{tabular}

"For each response, means followed by the same letter are not significantly different.

\section{TABLE 5}

Correlation matrix of plant height (PH), number of leaves (NL), internode length (INL), total dry weight (TDW), nitrogen (N), phosphorus $(\mathrm{P})$, sodium $(\mathrm{Na})$, and chloride $(\mathrm{Cl})$ content of grape rootstocks.

\begin{tabular}{|c|c|c|c|c|c|c|c|c|}
\hline & PH & NL & INL & TDW & $\mathbf{N}$ & $\mathbf{P}$ & $\mathrm{Na}$ & $\mathrm{Cl}$ \\
\hline PH & 1.00 & $0.70 * *$ & $0.78 * *$ & $0.77 * *$ & $0.66^{* *}$ & $0.56^{* *}$ & $-0.66 * *$ & $-0.58 * *$ \\
\hline NL & & 1.00 & $0.59^{* *}$ & $0.63^{* *}$ & $0.48^{* *}$ & $0.55^{* *}$ & $-0.57 * *$ & $-0.69 * *$ \\
\hline INL & & & 1.00 & $0.63^{* *}$ & $0.81 * *$ & $0.52 * *$ & $-0.53 * *$ & $-0.61 * *$ \\
\hline TDW & & & & 1.00 & $0.44 *$ & $0.58 * *$ & $-0.69 * *$ & $-0.67 * *$ \\
\hline $\mathbf{N}$ & & & & & 1.00 & $0.53 * *$ & $-0.46^{* *}$ & $-0.53 * *$ \\
\hline $\mathbf{P}$ & & & & & & 1.00 & $-0.78^{* *}$ & $-0.83 * *$ \\
\hline $\mathrm{Na}$ & & & & & & & 1.00 & $0.77 * *$ \\
\hline Cl & & & & & & & & 1.00 \\
\hline
\end{tabular}

*significantly different from zero at the $5 \%$ level, **significantly different from zero at the $1 \%$ level. 

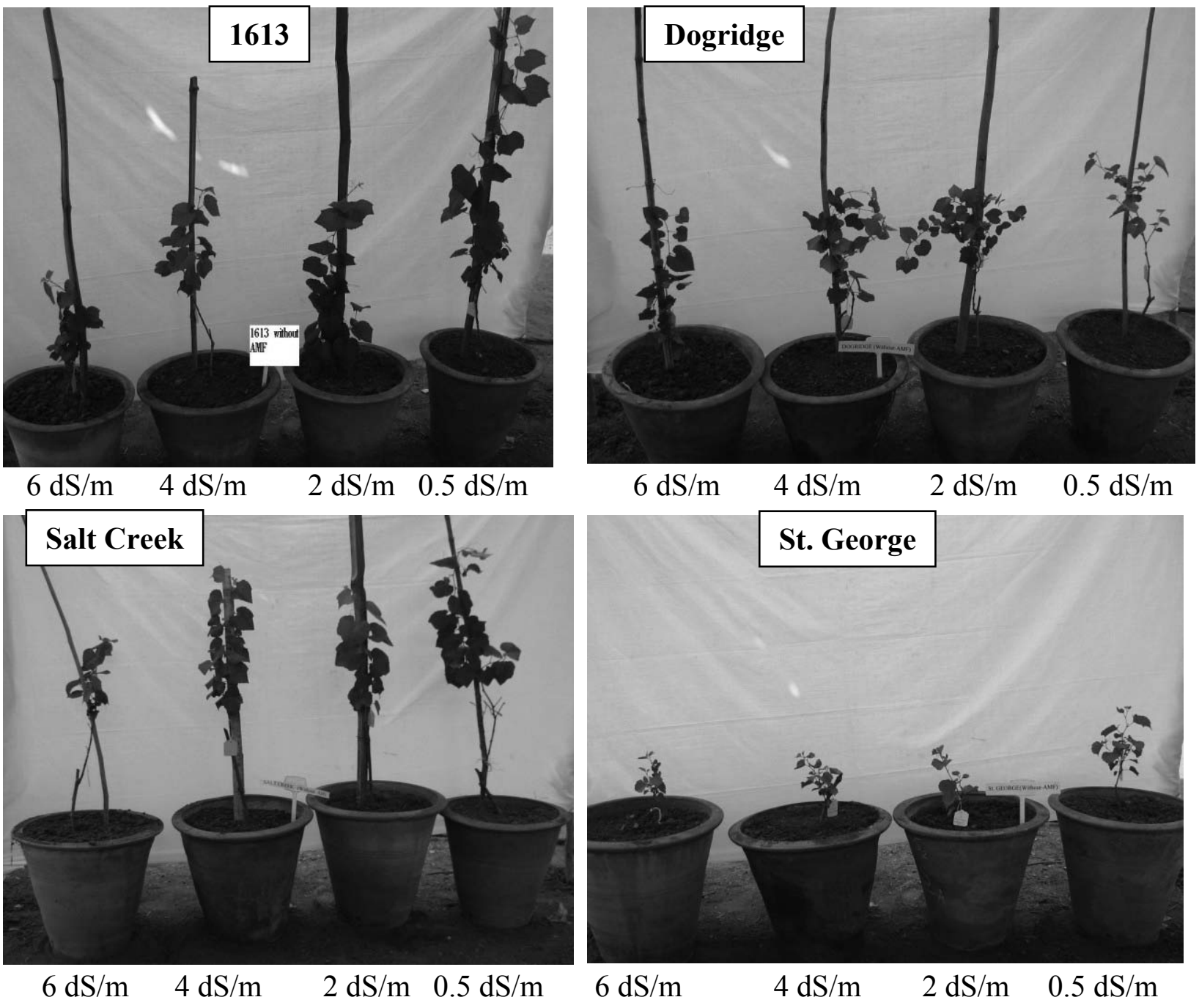

FIGURE 1

Illustration of how the growth of the four rootstocks (1613, Dogridge, Salt Creek and St. George) was affected differently by salinity (6, $4,2,0.5 \mathrm{dS} / \mathrm{m})$ when they were not inoculated with Glomus fasciculatum.

\section{DISCUSSION}

In the present investigation, increased salinity reduced plant growth (shoot length, internode length, number of leaves per vine, total dry weight, as well as root colonization by the AM fungus and spore count) in all the rootstocks tested. However, the extent of the reduction differed among the rootstocks. Shannon and Grieve (1999) reported that the range of salt concentrations tolerated by crops varied greatly from species to species, and between cultivars within species.

The sodium and chloride content of the grape rootstocks were highly negatively correlated with growth responses (Table 5), demonstrating the detrimental effects of both nutrients on plant growth. One of the mechanisms of the response of grapevines to salinity involves reduced biomass production as salinity increases as a result of the decreased osmotic potential of the soil solution (Shani \& Ben-Gal, 2005). Salinity reduces the water potential of the roots, causing reductions in growth rate, along with a suite of metabolic changes similar to those caused by water stress (Munns, 2002). From the present results it can be deduced that the reduction in plant growth due to increased salinity can be attributed to the osmotic effects of salt. Osmotic stress is a problem stemming from salt stress, and the resulting decrease in chemical activity causes cells to lose turgor (Serrano et al., 1999). Excess salt also causes increased expenditure of energy on maintenance respiration or ion transport, reduced energy for the translocation of carbohydrates, and diversion of photosynthates from growth to osmoregulation (Allen et al., 1994).

Our study showed a significant decrease in the number of leaves per vine as salinity increased. These results are in agreement with those of Sivritepe and Eris (1999), who found similar results working with some grapevine cultivars under in vitro conditions. The decrease in the number of leaves observed was attributable not only to the growth-inhibiting effects of salt, but also to the injurious effects of salt, which caused defoliation of the damaged leaves. This, we believe, is due to a decrease in soil water potential, followed by a specific salt injury in older leaves that die when their vacuoles cannot sequester any more salt. It should be noted that Munns (1993) has also reported that the accumulation of salt in the old leaves accelerates their death, and the loss of these leaves decreases the supply of carbohydrates or growth hormones 


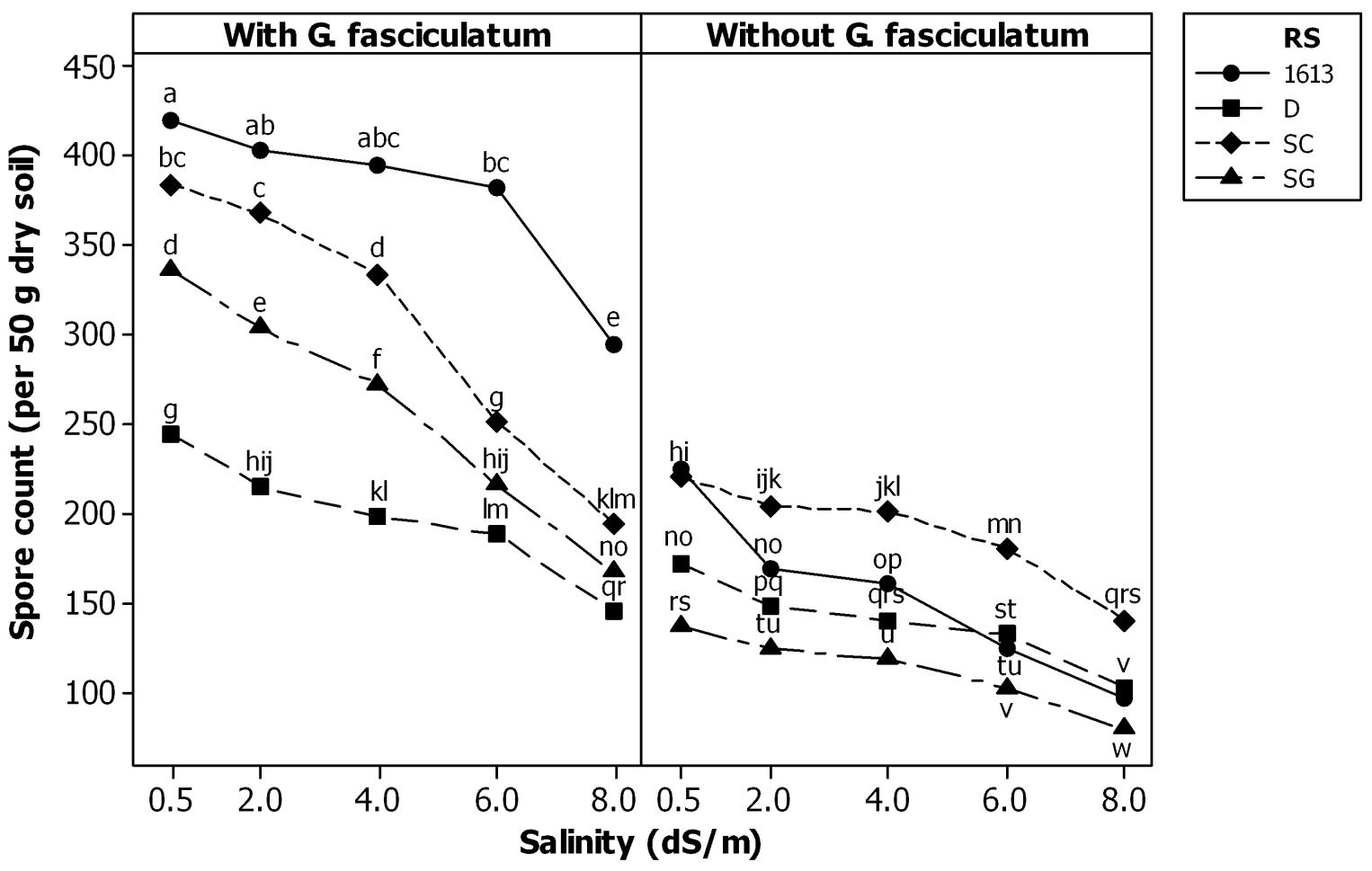

FIGURE 2

The interaction of inoculation (with and without Glomus fasciculatum), grape rootstock (RS: 1613, Dogridge [D], Salt Creek [SC] and St. George [SG]) and salinity (0.5, $2.0,4.0,6.0$, and $8.0 \mathrm{in} \mathrm{dS} / \mathrm{m}$ ) on spore count (spores $/ 50 \mathrm{~g}$ dry soil). Letter grouping shows comparison of all 40 treatment combinations of AM fungus, RS and salinity. Means sharing the same letter are not significantly different.

to meristematic regions, thereby inhibiting growth. In our study, the salt injury in older leaves could be due to excessive amounts of salt entering the plant, eventually rising to toxic levels in the older transpiring leaves, thereby causing premature senescence. A reduction in the number of leaves per shoot may also occur due to salinity-induced senescence of plant tissues resulting from increased production of abscisic acid (ABA) and ethylene (Kefu et al., 1991).

Total dry weight decreased with increasing salinity levels. The reduction in dry weight accumulation can be attributed to a decrease in plant growth in terms of shoot length, internode length and number of leaves per vine. As has been reported elsewhere, increased salinity has an inverse relationship with stomatal conductance and net photosynthetic rate (Curtis \& Lauchli, 1986), leading to reduced photo-assimilation and dry matter production (Rozeff, 1995).

It has been reported that mycorrhizal fungi improve plant survival and growth under saline conditions (Dixon et al., 1994). The primary benefit of arbuscular mycorrhiza is to increase the absorption and translocation of essential ions that are relatively immobile. A key factor that affects the potential for mycorrhizas to benefit plants in particular sites is the supply of $\mathrm{P}$ and $\mathrm{N}$ in the soil (Abbott \& Robson, 1991). Pearson \& Jakobsen (1993) reported that the symbiotic association with AM fungi allows the plant to access $\mathrm{P}$ beyond the depletion zone through the extraradical fungal hyphae and thereby augment $\mathrm{P}$ uptake by the root. In the present study, all rootstocks responded positively to mycorrhizal inoculation. The mycorrhizal symbiosis increased the vegetative growth of the rootstocks, mainly due to the increase in spore count and root colonisation. Fluctuations in spore densities have been found to be related to the phenological phase and the species (Camargo-Ricalde \& Esperon-Rodriguez, 2005). This may explain the higher spore production and root colonisation percentage in 1613, which in turn attained the highest shoot length and number of leaves per vine under saline conditions. Mycorrhizal inoculation significantly increased internode length in all the rootstocks studied. Various researchers (Al-Karaki et al., 2001; Yano-Melo et al., 2003) have reported the beneficial effect of AM fungi on plant growth under salt stress conditions. The increased vegetative growth observed could be attributed to the improved efficiency of nutrient absorption resulting from inoculation with AM fungi. Our findings confirm the earlier results of Johnson and Hummel (1985), Nemec and Vu (1990), and Vinayak and Bagyaraj (1990).

The rootstocks used in this experiment appeared to differ in soil salinity tolerance, and the overall growth performance of Dogridge and Salt Creek in a saline soil was better than that of rootstock 1613, which showed a moderate performance, while that of St. George was poor. This is in agreement with Satisha and Prakash (2006), who found Dogridge rootstock to have increased water-use efficiency compared to the other rootstocks in their experiment. Inoculation of the rootstocks with $G$. fasciculatum increased plant growth and dry matter accumulation. AM fungi function as an 
extension of the root system of the plant, increasing the absorptive area and improving the uptake of $\mathrm{P}$ and other nutrients with slow mobility (Camprubi et al., 2008). In the present investigation, mycorrhizal plants recorded a significantly higher $\mathrm{P}$ content (data not presented), suggesting the beneficial role of mycorrhiza in nutrient acquisition and improved plant growth.

\section{CONCLUSION}

The results of the present study clearly show that salt-tolerant rootstocks could be exploited for the better adaptation of grapes in the semi-arid and arid areas of India and elsewhere where grape production is constrained by soil salinity. Based on the overall growth and total dry matter accumulation responses, it can be concluded that the salt tolerance ranking (high to low) of the four rootstocks was Dogridge $>$ Salt Creek $>1613>$ St. George.

\section{LITERATURE CITED}

Abbott, L.K. \& Robson, A.D., 1991. Factors influencing the occurrence of vescular-arbuscular mycorrhizas. Agr. Ecosyst. Environ. 35, 121-150.

Agaoglu, Y.S., Ergul, A. \& Aras, S., 2004. Molecular characterization of salt stress in grapevine cultivars (Vitis vinifera L.) and rootstocks. Vitis 43, 107-110.

Alexander, M., 1982. Most probable number method for microbial populations. In: Black, C.A. (ed). Methods of soil analysis. American Society of Agronomy, Madison, WI, pp $815-820$.

Aliasgharzadeh, N., Rastin, N.S., Towfighi, H. \& Alizadeh, A., 2001. Occurrence of arbuscular mycorrhizal fungi in saline soils of the Tabriz plain of Iran in relation to some physical and chemical properties of soil. Mycorrhiza 11, 119-122.

Al-Karaki, G.N., Hammad, R. \& Rusan, M., 2001. Response of two tomato cultivars differing in salt tolerance to inoculation with mycorrhizal fungi under salt stress. Mycorrhiza 11, 43-47.

Allen, J.A., Chambers, J.L. \& Stine, M., 1994. Prospects for increasing salt tolerance of forest trees: a review. Tree Physiol. 14, 843-853.

Apse, M.P., Dharon, G.S., Snedden, W.A. \& Bumerold, E., 1999. Salt tolerance conferred by overexpression of a vacuolar $\mathrm{Na}+/ \mathrm{H}+$ antiport in Arabidopsis. Science $285,1256-1258$.

Asghari, H., Marschner, P., Smith, S. \& Smith, F., 2005. Growth response of Atriplex nummularia to inoculation with arbuscular mycorrhizal fungi at different salinity levels. Plant Soil 273, 245-256.

Camprubi, A., Estaun, V., Nogales, A., Pitet, M. \& Calvet, C., 2008. Response of the grapevine rootstock Richter 110 to inoculation with native and selected arbuscular mycorrhizal fungi and growth performance in a replant vineyard. Mycorrhiza 18, 211-216.

Camargo-Ricalde, S.L. \& Esperon-Rodriguez, M., 2005. Efecto de la heterogeneidad espacial y estacional del suelo sobre la abundancia de esporas de hongos micorrizógenos arbusculares en el valle semiárido de Tehuacán-Cuicatlán, México. Rev. Biol. Trop. 53, 339-352.

Curtis, P.S. \& Lauchli, A., 1986. The role of leaf area development and photosynthetic capacity in determining growth of Kenaf under moderate salt stress. Aust. J. Plant Physiol. 13, 553-565.

Dixon, R.K., Rao, M.V. \& Garg, V.K., 1994. Water relations and gas exchange of mycorrhizal Leucaena leucocephala seedlings. J. Trop. For. Sci. 6, 542-552.

Downton, W.J.S., 1977. Photosynthesis in salt-stressed grapevines. Aust. J. Plant Physiol. 4, 183-192.

Gerdemann, J.W. \& Nicolson, T.H., 1963. Spores of mycorrhizal Endogone species extracted from soil by wet sieving and decanting. Trans. Br. Mycol. Soc. $46,235-244$.

Giovanetti, M. \& Mosse, B., 1980. An evaluation of techniques for measuring vesicular-arbuscular mycorrhizal infections in roots. New Phytol. 84, 489-500.

Giri, B., Kapoor, R. \& Mukerji, K.G., 2003. Influence of arbuscular mycorrhizal fungi and salinity on growth, biomass and mineral nutrition of Acacia auriculiformis. Biol. Fert. Soils 38, 170-175.
Giri, B., Kapoor, R. \& Mukerji, K.G., 2007. Improved tolerance of Acacia nilotica to salt stress by arbuscular mycorrhiza, Glomus fasciculatum may be partly related to elevated $\mathrm{K} / \mathrm{Na}$ ratios in root and shoot tissues. Microb. Ecol. 54, 753-760.

Giri, B. \& Mukerji, K.G., 2004. Mycorrhizal inoculants alleviate salt stress in Sesbania aegyptiaca and Sesbania grandiflora under field conditions: evidence for reduced sodium and improved magnesium uptake. Mycorrhiza. 14, 307-312.

Hasegawa, P.M., Bressan, R.A., Zhu, J.K. \& Bohnert, H.J., 2000. Plant cellular and molecular responses to high salinity. Annu. Rev. Plant Physiol. Plant Mol. Biol. 51, 463-499.

Johnson, C.R. \& Hummel, R.L., 1985. Influence of mycorrhizae and drought stress on growth of Poncirus x Citrus seedlings. HortScience 20, 754-755.

Kefu, Z., Munns, R. \& King, R.W., 1991. Abscisic acid levels in NaCl-treated barley, cotton, and saltbush. Aust. J. Plant Physiol. 18, 17-24.

Marschner, H. \& Dell, B., 1994. Nutrient uptake in mycorrhizal symbiosis. Plant Soil 159, 89-102.

Montgomery, D.C., 2009 ( $7^{\text {th }}$ ed). Design and analysis of experiments. John Wiley and Sons, NY.

Munns, R., 1993. Physiological responses limiting plant growth in saline soils: some dogmas and hypotheses. Plant Cell Environ. 16, 15-24.

Munns, R., 2002. Comparative physiology of salt and water stress. Plant Cell Environ. 25, 239-250.

Nemec, S. \& Vu, J.C.V., 1990. Effect of soil phosphorus and Glomus intraradices on growth, nonstructural carbohydrates and photosynthetic activity of Citrus aurantium. Plant Soil 128, 257-263.

Payne, G., Middlesteadt, W., Williams, S., Desai, N., Parks, D., Dincher, S., Carnes, M. \& Ryals, J., 1988. Isolation and nucleotide sequence of a novel cDNA clone encoding the major form of pathogenesis-related protein R. Plant Mol. Biol. 11, 223-224.

Pearson, J.N. \& Jakobsen, I., 1993. The relative contribution of hyphae and roots to phosphorus uptake by arbuscular mycorrhizal plants, measured by dual labelling with ${ }^{32} \mathrm{P}$ and ${ }^{33} \mathrm{P}$. New Phytol. 124, 489-494.

Pierpoint, W.S., Jackson, P.J. \& Evans, R.M., 1990. The presence of a thaumatinlike protein, a chitinase and a glucanase among the pathogenesis-related proteins of potato (Solanum tuberosum). Physiol. Mol. Plant Pathol. 36, 325-338.

Phillips, J.M. \& Hayman, D.S., 1970. Improved procedure for clearing roots and staining parasitic and vesicular-arbuscular mycorrhizal fungi for rapid assessment of infection. Trans. Br. Mycol. Soc. 55, 158-161.

Rabie, G.H., 2005. Influence of arbuscular mycorrhizal fungi and kinetin on the response of mungbean plants to irrigation with seawater. Mycorrhiza 15, 225230.

Rozeff, N., 1995. Sugarcane and salinity - a review paper. Sugarcane 5, 8-19.

Ruiz-Lozano, J.M. \& Azcon, R., 1995. Hyphal contribution to water uptake in mycorrhizal plants as affected by the fungal species and water status. Physiol. Plant. 95, 472-478.

SAS, 2003. SAS/STAT User's Guide, Version 9.1. SAS Institute Inc., Cary, NC.

Satisha, J. \& Prakash, G.S., 2006. The influence of water and gas exchange parameters on grafted grapevines under conditions of moisture stress. S. Afr. J. Enol. Vitic. 27, 40-45.

Serrano, R., Culianz-Macia, F. \& Moreno, V., 1999. Genetic engineering of salt and drought tolerance with yeast regulatory genes. Sci. Hortic. 78, 261-269.

Shani, U. \& Ben-Gal, A., 2005. Long-term response of grapevines to salinity: osmotic effects and ion toxicity. Am. J. Enol. Vitic. 56, 148-154.

Shannon, M.C. \& Grieve, C.M., 1999. Tolerance of vegetable crops to salinity. Sci. Hortic. 78, 5-38.

Singh, M. \& Sharma, J.K., 2005. Effect of rootstocks on disease intensity of Perlette grape vine. Haryana J. Hortic. Sci. 34, 234-235.

Sivritepe, N. \& Eris, A., 1999. Determination of salt tolerance in some grapevine cultivars (Vitis vinifera L.) under in vitro conditions. Trop. J. Biol. 23, 473-485.

Vinayak, K. \& Bagyaraj, D.J., 1990. Selection of efficient VAM mycorrhizal fungi for Trifoliate orange. South Indian Horticulture 6, 305-311.

Volkmar, K.M., Hu, Y. \& Steppuhn, H., 1998. Physiological responses of plants to salinity: a review. Can. J. Plant Sci. 78, 19-27.

Yano-Melo, A.M., Saggin, O.J. \& Costa, M.L., 2003. Tolerance of mycorrhized banana (Musa sp. cv. Pacovan) plantlets to saline stress. Agric. Ecosyst. Environ. 95, 343-348. 